\title{
Front Matter: Volume 10525
}

, "Front Matter: Volume 10525," Proc. SPIE 10525, High-Power Laser Materials Processing: Applications, Diagnostics, and Systems VII, 1052501 (7 May 2018); doi: 10.1117/12.2322859

SPIE. Event: SPIE LASE, 2018, San Francisco, California, United States 


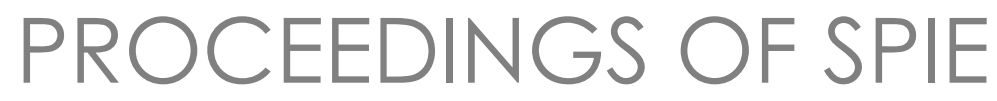

\section{High-Power Laser Materials Processing: Applications, Diagnostics, and Systems VII}

Stefan Kaierle

Stefan W. Heinemann

Editors

31 January - 1 February 2018

San Francisco, California, United States

Sponsored and Published by

SPIE

Volume 10525 
The papers in this volume were part of the technical conference cited on the cover and title page. Papers were selected and subject to review by the editors and conference program committee. Some conference presentations may not be available for publication. Additional papers and presentation recordings may be available online in the SPIE Digital Library at SPIEDigitalLibrary.org.

The papers reflect the work and thoughts of the authors and are published herein as submitted. The publisher is not responsible for the validity of the information or for any outcomes resulting from reliance thereon.

Please use the following format to cite material from these proceedings:

Author(s), "Title of Paper," in High-Power Laser Materials Processing: Applications, Diagnostics, and Systems VII, edited by Stefan Kaierle, Stefan W. Heinemann, Proceedings of SPIE Vol. 10525 (SPIE, Bellingham, WA, 2018) Seven-digit Article CID Number.

ISSN: 0277-786X

ISSN: 1996-756X (electronic)

ISBN: 9781510615359

ISBN: 9781510615366 (electronic)

Published by

SPIE

P.O. Box 10, Bellingham, Washington 98227-0010 USA

Telephone +1 3606763290 (Pacific Time) · Fax +1 3606471445

SPIE.org

Copyright (C) 2018, Society of Photo-Optical Instrumentation Engineers.

Copying of material in this book for internal or personal use, or for the internal or personal use of specific clients, beyond the fair use provisions granted by the U.S. Copyright Law is authorized by SPIE subject to payment of copying fees. The Transactional Reporting Service base fee for this volume is $\$ 18.00$ per article (or portion thereof), which should be paid directly to the Copyright Clearance Center (CCC), 222 Rosewood Drive, Danvers, MA 01923. Payment may also be made electronically through CCC Online at copyright.com. Other copying for republication, resale, advertising or promotion, or any form of systematic or multiple reproduction of any material in this book is prohibited except with permission in writing from the publisher. The CCC fee code is 0277$786 \mathrm{X} / 18 / \$ 18.00$.

Printed in the United States of America.

Publication of record for individual papers is online in the SPIE Digital Library.

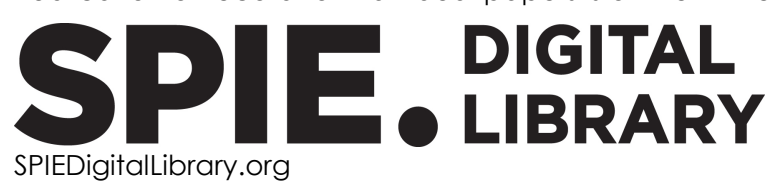

Paper Numbering: Proceedings of SPIE follow an e-First publication model. A unique citation identifier (CID) number is assigned to each article at the time of publication. Utilization of CIDs allows articles to be fully citable as soon as they are published online, and connects the same identifier to all online and print versions of the publication. SPIE uses a seven-digit CID article numbering system structured as follows:

- The first five digits correspond to the SPIE volume number.

- The last two digits indicate publication order within the volume using a Base 36 numbering system employing both numerals and letters. These two-number sets start with $00,01,02,03$, 04, 05, 06, 07, 08, 09, 0A, OB ... 0Z, followed by 10-1Z, 20-2Z, etc. The CID Number appears on each page of the manuscript. 


\title{
Contents
}

\author{
$\checkmark$ Authors \\ vii Conference Committee
}

\section{LASE PLENARY SESSION}

$1052502 \quad$ Advanced industrial laser systems and applications (Plenary Paper) [10525-203]

SESSION 1 SYSTEMS I

1052503 The Laser Megajoule facility: laser performances and comparison with computational simulation [10525-1]

1052504 Multi-physical modeling of thermal and dispersive effects in optical systems for high power ultra-short laser pulses [10525-2]

1052505 Tuneable UV solid-state laser lines for surface processing [10525-3]

1052506 Influence of thermally induced aberrations on resulting intensity distribution [10525-4]

1052507 Beam shaping of focused radiation of multimode lasers [10525-5]

SESSION 2 SYSTEMS II

1052508 Improving accuracy of robot-guided 3D laser surface processing by workpiece measurement in a blink [10525-6]

1052509 Mobile laser cutting system for complex rescue operations [10525-7]

10525 OA Ball-shaped end caps for fiber laser systems [10525-8]

10525 OB Measurement of the dispersion properties of large aperture mirrors at arbitrary incidence angle and polarization state [10525-9]

\section{SESSION 3 WELDING AND CUTTING}

10525 OC Brightline weld-spatter reduced high speed welding with disk lasers [10525-1 1]

10525 OD Pores in laser beam welding: generation mechanism and impact on the melt flow [10525-12]

10525 OE New welding techniques and laser sources for battery welding [10525-13] 
$10525 \mathrm{OF} \quad$ New milestones in laser cutting for quality improvement and process automation [10525-26]

\section{SESSION 4 SURFACE TREATMENT I}

$105250 G$ Research on inorganic cladding of neodymium phosphate glass in slab amplifier [10525-15]

$10525 \mathrm{OH}$ Backscattered light properties during femtosecond laser ablation and development of a dynamic interferometric focusing system [10525-16]

$10525 \mathrm{Ol}$ Laser beam ablation of thick steel plates without affecting the material underneath [10525-17]

$10525 \mathrm{OJ}$ Femtosecond pulsed laser deposition of a boron thin film aiming at the development of a low-cost neutron detector [10525-18]

$10525 \mathrm{OL}$ Approaches for increasing process rate of local 3D laser decoating for series production of hybrid composites [10525-20]

\section{SESSION 5 SURFACE TREATMENT II}

10525 OM Influence of operating parameters on morphology of laser hardened surfaces [10525-22]

10525 ON Development of high power laser ablation process for polycrystalline diamond polishing: Part 1. Fundamental understanding of PCD ultra-short pulsed laser ablation [10525-23]

1052500 High pulse energy kW average power nanosecond lasers enable breakthrough in rapid coating removal [10525-24] 


\title{
Authors
}

Numbers in the index correspond to the last two digits of the seven-digit citation identifier (CID) article numbering system used in Proceedings of SPIE. The first five digits reflect the volume number. Base 36 numbering is employed for the last two digits and indicates the order of articles within the volume. Numbers start with 00, 01, 02, 03, 04, 05, 06, 07, 08, 09, OA, OB...0Z, followed by 10-12, 20-2Z, etc.

\author{
Airiau, J.-P., 03 \\ Amaral, Marcello Magri, $\mathrm{OH}$ \\ Beau, V., 03 \\ Berger, Peter, OD \\ Bonhoff, Tobias, 04 \\ Bordenave, E., 03 \\ Borzsonyi, A., OB \\ Brodesser, Alexander, 09 \\ Chard, Simon, 00 \\ Chies, T., 03 \\ Costa, Priscila, 0J \\ Dai, DeChang, 00 \\ Denis, V., 03 \\ De Pretto, Lucas, $\mathrm{OH}$ \\ Dold, Eva, OE \\ Emonts, Michael, 08, OL \\ Faisst, Birgit, $\mathrm{OE}$ \\ Fetzer, Florian, OD \\ Feuchtenbeiner, S., OC \\ Fischer, Kai, 08, 0L \\ Freitas, Anderson Zanardi, $\mathrm{OH}$ \\ Frühauf, Boris, 08 \\ Gabzdyl, Jack, OE \\ Gaussmann, Fabian, 05 \\ Genezini, Frederico Antônio, 0J \\ Graf, Thomas, OD \\ Grafe, Robert, 09 \\ Grimm, Vyacheslav, 05 \\ Haug, P., OC \\ Havrilla, D., OC \\ Hennigs, Christian, 09 \\ Hermsdorf, J., Ol \\ Hesse, Tim, OC, OE \\ Heyrick, Jan, OF \\ Hoff, C., Ol \\ Holtz, Ronald, ON \\ Hu, Haoyue, OD \\ Hustedt, Michael, 09 \\ Ivanenko, Mikhail, 05 \\ Julien, X., 03 \\ Kaierle, Stefan, 09, 01 \\ Kaiser, Elke, OE \\ Kalis, Henning, 05 \\ Kirchhoff, Marc, OE \\ Kogel-Hollacher, Markus, OF \\ Kovacs, M., OB \\ Kwon, Young Key, 00 \\ Lacampagne, L., 03 \\ Lacombe, C., 03
}

Laffir, Fathima, ON

Laskin, Alexander, 06, 07

Laskin, Vadim, 06, 07

Li, Haiyuan, OG

$\mathrm{Li}$, Yangshuai, OG

Loosen, Peter, 04

Machado, Noé Gabriel Pinheiro, 0J

Maharjan, Niroj, OM

McComb, Timothy S., 00

Metsios, loannis, 00

Moser, Rüdiger, 08

Ostrun, Aleksei, 06, 07

Overmeyer, L., Ol

Pantsar, Henrikki, OE

Raele, Marcus Paulo, $\mathrm{OH}, \mathrm{OJ}$

Rudolf, Andreas, OF

Samad, Ricardo Elgul, $\mathrm{OH}, \mathrm{OJ}$

Scalbert, William, ON

Schaefer, M., 02

Schares, Richard, 08, 0L

Schmidt, B., 02

Schmitt, Stefan, 08, 0L

Seres, I., OB

Sipos, A., OB

Somoskoi, T., OB

Sozet, M., 03

Speker, N., OC

Stollenwerk, Jochen, 04

Tanner, David, ON

Vermersch, S., 03

Vieira, Nilson Dias, Jr., $\mathrm{OH}, \mathrm{OJ}$

Volpp, Joerg, 07

Wang, Bingyan, OG

Weber, Rudolf, OD

Wetter, Niklaus U., $\mathrm{OH}$

Wiesner, Markus, 05

Wu, Naien, OM

Xiong, Huai, OG

Zhang, Yanli, OG

Zheng, Wenxin, OA

Zhou, Shenlei, OG

Zhou, Wei, OM

Zhou, Yu, OM

Zhu, Gongwen, OA

Zhu, Jianqiang, $0 \mathrm{G}$ 
Proc. of SPIE Vol. 10525 1052501-6

Downloaded From: https://www.spiedigitallibrary.org/conference-proceedings-of-spie on 26 Apr 2023 Terms of Use: https://www.spiedigitallibrary.org/terms-of-use 


\section{Conference Committee}

Symposium Chairs

Koji Sugioka, RIKEN (Japan)

Reinhart Poprawe, Fraunhofer-Institut für Lasertechnik (Germany)

Symposium Co-Chairs

Xianfan Xu, Purdue University (United States)

Beat Nevenschwander, Berner Fachhochschule Technik und Informatik (Switzerland)

Program Track Chairs

Bo Gu, Bos Photonics (United States)

Stefan Kaierle, Laser Zentrum Hannover e.V. (Germany)

Conference Chairs

Stefan Kaierle, Laser Zentrum Hannover e.V. (Germany)

Stefan W. Heinemann, TRUMPF Photonics (United States)

Conference Program Committee

Bo Gu, Bos Photonics (United States)

Klaus R. Kleine, Coherent, Inc. (United States)

Annett Klotzbach, Fraunhofer IWS Dresden (Germany)

Wolfgang Knapp, Cooperation Laser Franco-Allemande (France)

Lin Li, The University of Manchester (United Kingdom)

Silke Pflueger, Consultant (United States)

Stephan Roth, BLZ Bayerisches Laserzentrum GmbH (Germany)

Leonardo D. Scintilla, Politecnico di Bari (Italy)

Stefaan Vandendriessche, Edmund Optics Inc. (United States)

Kunihiko Washio, Paradigm Laser Research Ltd. (Japan)

Session Chairs

1 Systems I

Stefan Kaierle, Laser Zentrum Hannover e.V. (Germany)

2 Systems II

Stefan Kaierle, Laser Zentrum Hannover e.V. (Germany) 


\section{Welding and Cutting}

Stefan W. Heinemann, TRUMPF Photonics (United States)

4 Surface Treatment I

Lin Li, The University of Manchester (United Kingdom)

5 Surface Treatment II

Kunihiko Washio, Paradigm Laser Research Ltd. (Japan) 